\title{
Nuclear DNA content in Chilean species of Phycella and Rhodolirium (Amaryllidaceae)
}

\section{Contenido de ADN nuclear en especies chilenas de Phycella y Rhodolirium (Amaryllidaceae)}

\author{
Claudio Palma-Rojas ${ }^{1 *}$, Pedro Jara-Seguel ${ }^{2}$ \& Elisabeth von Brand ${ }^{3}$ \\ ${ }^{1}$ Departamento de Biología, Facultad de Ciencias, Universidad de La Serena, Casilla 599, La Serena-Chile. \\ ${ }^{2}$ Escuela de Ciencias Ambientales, Facultad de Recursos Naturales, Universidad Católica de Temuco, Casilla 15-D, Temuco, \\ Chile. \\ ${ }^{3}$ Departamento de Biología Marina, Facultad de Ciencias del Mar, Universidad Católica del Norte, Casilla 117, Coquimbo, \\ Chile. \\ *cpalma@userena.cl
}

\begin{abstract}
RESUMEN
Las determinaciones de ADN nuclear realizadas muestran que el valor $2 \mathrm{C}$ para Rhodolirium montanum $\mathrm{Phil}$. $(2 \mathrm{n}=2 \mathrm{x}=16)$ es de 17,39 pg y de 15,16 pg para Phycella ignea (Lindl.) Lindl. $(2 \mathrm{n}=2 \mathrm{x}=16)$. Sin embargo, el tetraploide Phycella scarlatina Ravenna $(2 \mathrm{n}=4 \mathrm{x}=32)$ tiene un valor de ADN 2C de 30,63 pg, el cual es concordante con su nivel de ploidía.
\end{abstract}

Angiosperms are the most intensively studied major group of organisms with published C-values varying about 2000 -fold for a number over 4,400 studied species (Leitch et al. 2010). However, C-values for South American plants are scarce, which has been a preoccupation for researchers interested in study trends on genome size evolution of global floras (Bennett \& Leitch 2005). In the case of Chilean angiosperms only 12 continental species have been studied and belong to seven families (ca. $0.24 \%$ of the Chilean angiosperms).

Rhodolirium and Phycella are two genera belonging to Amaryllidaceae that inhabit Chile. C-values have not been published for Chilean species of Amaryllidaceae, and only a previous contribution has been documented for species of the genera Amaryllis and Hippeastrum (Naranjo \& Poggio 1988).

In this work the nuclear DNA content of Rhodolirium montanum Phil. [= Rhodophiala rhodolirion (Baker) Traub], Phycella ignea (Lindl.) Lindl., and Phycella scarlatina Ravenna from Central Chile are estimated for the first time, thus increasing the knowledge on $2 \mathrm{C}$-values with data for two additional genera within Amaryllidaceae.

Plants of one accession of each species were collected from naturally growing populations. The voucher specimens were deposited at the herbarium from the Universidad de La Serena (ULS herbarium). The collection sites are shown in Table I. Measurements of nuclear DNA content (2C-values) were done by fluorescent microdensitometry in telophase nuclei of root tip cells obtained from five bulbs by each species. The root tips were fixed in ethanol-glacial acetic acid $(3: 1 \mathrm{v} / \mathrm{v})$ and stored in ethanol at $4^{\circ} \mathrm{C}$. The root tips were stained using fluorescent Feulgen reaction (Prenna et al. 1974). The meristems were squashed onto glass slides, and the amount of fluorescence emitted by each telophase nucleus was measured using a Carl Zeiss Microscope Fluorometer (O'Neill et al. 1988). The fluorescent emissions (FE) contributed by each nucleus were estimated in arbitrary units. For the sampled species, FE values of 150 telophase (2C) nuclei were determined. The FE values in arbitrary units were converted into absolute mass of DNA (in picograms, pg) by comparison with root tip cells in telophase of Allium cepa $(2 \mathrm{C}=33.5 \mathrm{pg}, 2 \mathrm{n}=16)$ (Johnston et al. 1999, Bennett \& Leitch 2005).

Nuclear DNA content and chromosome numbers of Rhodolirium montanum, Phycella ignea and P. scarlatina are given in Table I. The higher 2C-value was estimated in P. scarlatina (30.6 pg) followed in decreasing order by R. montanum (17.3 pg) and $P$. ignea $(15.1 \mathrm{pg})$. In all three cases the coefficient of variation was lower than $7.9 \%$. The 2C-values of $R$. montanum and $P$. ignea are lower to the range reported for Amaryllidaceae which vary from 28 to ca. 164.3 pg (Leitch et al. 2005, 2010). A similar situation was observed comparing both species with the diploid taxa of Hippeastrum (range from 26.9 to $31.4 \mathrm{pg}$ ) (Naranjo \& Poggio 1988). In the case of P. scarlatina its $2 \mathrm{C}$-value is within the range described for Amaryllidaceae, being near to the recorded for some Hippeastrum species. 
On the other hand, all the three examined species showed a basic chromosome number $\mathrm{x}=8$, where $R$. montanum and $P$. ignea have a chromosome number $2 \mathrm{n}=2 \mathrm{x}=16$, while $P$. scarlatina had $2 \mathrm{n}=4 \mathrm{x}=32$ (Palma-Rojas 2000, Muñoz et al. 2011). Interestingly, $P$. scarlatina doubled in $2 \mathrm{n}$ the number of both $P$. ignea and $R$. montanum, which is coincident with the doubling in $2 \mathrm{C}$-value. These results corroborate the preliminary data described by Palma-Rojas
(2000) for the same species who suggested tetraploidy for $P$. scarlatina (likely allotetraploidy).

In Chile, ca. 43 species are recognized within Amaryllidaceae and belong to seven genera (Hoffmann 1989). Thus, 2C-values have been estimated only for ca. $6.9 \%$ of the Chilean species. Then, additional studies need to be carried out to complete the knowledge on genome size within this native family.

TABLE I. Collection sites, chromosome number and 2C DNA content for the examined Rhodolirium and Phycella species. FE, fluorescence emission in arbirary units; $\mathrm{SD}$, standard deviation.

TABla I. Sitios de colecta, número cromosómico y contenido 2C de ADN para las especies examinadas de Rhodolirium y Phycella. FE, emisión de fluorescencia en unidades arbitrarias; $\mathrm{SD}$, desviación estándar.

\begin{tabular}{|c|c|c|c|c|}
\hline TAXA & Collection sites & $2 n$ & $\mathrm{FE}$ & $\begin{array}{l}\text { 2C-VALUE }(\mathrm{pg}) \\
\operatorname{MEAN} \pm \mathrm{SD}\end{array}$ \\
\hline Rhodolirium montanum & $\begin{array}{l}\text { Metropolitana. Prov. Santiago, La Parva, altitude 2,683masl, } \\
\left(33^{\circ} 20^{\prime} \text { S- } 70^{\circ} 17^{\prime} \text { W). 29-I-2009.C.Palma. }\right.\end{array}$ & 16 & 34.78 & $17.3 \pm 1.27$ \\
\hline Phycella ignea & $\begin{array}{l}\text { Metropolitana. Prov. Santiago, Loma Las Burras, altitude 531masl } \\
\left(33^{\circ} 27^{\prime} \text { S- } 70^{\circ} 50^{\prime} \mathrm{W}\right) .24-\mathrm{X}-2009 . \text { C.Palma. }\end{array}$ & 16 & 30.32 & $15.1 \pm 1.20$ \\
\hline P. scarlatina & $\begin{array}{l}\text { Coquimbo. Prov. Elqui, Quebrada El Arrayán, altitude 108masl } \\
\left(29^{\circ} 49^{\prime} \mathrm{S} ; 71^{\circ} 07^{\prime} \mathrm{W}\right) .05-\mathrm{IX}-2009 \text {. C.Palma. }\end{array}$ & 32 & 61.26 & $30.6 \pm 1.79$ \\
\hline
\end{tabular}

\section{ACKNOWLEDGMENTS}

To the projects FONDEF D98I-1044 and D02I-1095 by financing partially this work.

\section{BIBLIOGRAPHY}

Bennett, M. \& I. Leitch. 2005. Nuclear DNA amounts in Angiosperms: Progress, problems and prospects. Annals of Botany 95: 45-90.

Hoffmann, A. 1989. Chilean monocotyledonous geophytes taxonomic considerations and their state of conservation. Herbertia 45(1): 14-28.

Johnston J.S., M.D. Bennett, A.L. Rayburn, D.W. Galbraith \& H.J. PRICE. 1999. Reference standards for determination of DNA content of plant nuclei. American Journal of Botany 86: 609-613.

Leitch, I., D. Soltis, P. Soltis \& M. Bennett. 2005. Evolution of DNA amounts across land plants (Embryophyta). Annals of Botany 95: 207-217.

Leitch, I., J. Beaulieu, M. Chase, A. Leitch \& M. Fay. 2010. Genome size dynamics and evolution in Monocots.
Journal of Botany 2010: 18 pp. URL: http://www.hindawi. com/journals/jb/http://www.hindawai.com/journals/ jb/2010/862516/cta/ (accessed May 28, 2011).

Muñoz, M., R. Riegel, P. Seeman, P. Peñailillo, F. Schiappacasse \& J. NúÑEz. 2011. Relaciones filogenéticas de Rhodolirium montanum Phil. y especies afines, basadas en secuencias nucleotídicas de la región ITS y análisis cariotípico. Gayana Botánica 68(1): 40-48.

Naranjo, C. \& L. Poggio. 1988. A comparison of karyotype, AgNOR bands and DNA content in Amaryllis and Hippeastrum (Amaryllidaceae). Kew Bulletin 43: 317-325.

O'Neill, P., M.B. Singh \& R.B. Knox. 1988. Cell biology of the stigma of Brassica campestris in relation to $\mathrm{CO}_{2}$ effects on self-pollination. Journal of Cell Science 89: 541-549.

Palma-Rojas, C. 2000. Caracterización citogenética de los géneros Rhodophiala Presl. y Phycella Lindl. (Amaryllidaceae). En: P. Peñailillo, F. Schiappacasse (eds.), Los geófitos nativos y su importancia en la floricultura: Fundación para la Innovación Agraria (FIA) y Dirección de Investigación, Universidad de Talca (DIUT), Santiago, Chile, pp. 73-79.

Prenna, R., S. Leiva \& G. MazzinI. 1974. Quantitation of DNA by cytofluorometry of the conventional Feulgen reaction. Histochemical Journal 6: 467-484.

Recibido: 04.07.11

Aceptado: 26.08.11 